\title{
Peningkatan Hasil Belajar IPA dengan Modifikasi Literasi Sains dan Bridge Card pada Pokok Bahasan Kelangsungan Hidup Makhluk Hidup
}

\author{
Dwi Handayani \\ Madrasah Tsanawiyah Negeri 4 Ngawi \\ Jl. Raya Ngawi-Jogorogo KM.19, Kabupaten Ngawi, Jawa Timur 63253 \\ *Email: d.handayaningrum@gmail.com
}

\begin{abstract}
Abstrak
Penelitian ini bertujuan untuk meningkatkan hasil belajar IPA siswa kelas IXA MTsN 4 Ngawi pada pokok bahasan kelangsungan hidup makhluk hidup melalui modifikasi literasi sains dan bridge card. Jenis penelitian ini merupakan penelitian tindakan kelas. Teknik pengumpulan data menggunakan angket, observasi dan tes. Jumlah putaran dalam penelitian tindakan kelas sebanyak dua siklus yang terdiri dari tahap perencanaan, tindakan, observasi dan refleksi. Adapun teknik analisis data menggunakan deskriptif analitik. Hasil penelitian menemukan bahwa model pembelajaran dengan memodifikasi literasi sains dan bridge card memiliki dampak positif dalam meningkatkan kemampuan siswa pada materi Kelangsungan Hidup Makhluk Hidup di kelas IX E MTsN 4 Ngawi yang ditandai dengan peningkatan ketuntasan belajar siswa dalam setiap siklus. Peningkatan hasil belajar siswa pada siklus I siswa mencapai 66,66 \%, sedangkan siklus II sebesar 83,33 $\%$. Siklus I belum mencapai kriteria ketuntasan sedangkan siklus II telah mencapai kriteria ketuntasan dengan kenaikan $16,67 \%$. Rata-rata aktivitas siswa pada siklus 1 masih kurang yaitu sebesar 76,5\%, akan tetapi ratarata aktivitas siswa pada siklus II sebesar $90 \%$ dengan kategori aktif. Terjadi peningkatan aktivitas siswa sebesar $13,34 \%$. Peningkatan ini terutama pada aktivitas diskusi antar siswa dan kemauan siswa dalam menyampaikan pendapatnya. Hal Ini menunjukkan siswa semakin termotivasi dalam belajar IPA pada materi Kelangsungan Hidup Makhluk Hidup.
\end{abstract}

Kata kunci: Hasil Belajar, Modifikasi, Literasi Sains, Bridge Card

\begin{abstract}
This research aims to improve the learning outcomes of IPA students of class IXA MTsN 4 Ngawi on the subject of survival of living things through modification of science literacy and bridge card. This type of research is class action research. Data collection techniques use questionnaires, observations and tests. The number of rounds in class action research is as many as two cycles consisting of stages of planning, action, observation and reflection. Data analysis techniques use descriptive analytics. The results of the study found that the learning model by modifying science literacy and bridge cards had a positive impact in improving students' abilities on living living living materials in class IX E MTsN 4 Ngawi which was characterized by an increase in the completion of student learning in each cycle. The increase in student learning outcomes in the first cycle of students reached $66.66 \%$, while the second cycle was $83.33 \%$. Cycle I has not reached the completion criteria while cycle II has reached the completion criteria with an increase of $16.67 \%$. The average student activity in cycle 1 is still lacking, which is $76.5 \%$, but the average student activity in cycle II is $90 \%$ with the active category. In cycle II the average student activity has reached the active category (90\%). There was a $13.34 \%$ increase in student activity. This increase is mainly in discussion activities between students and the willingness of students in expressing their opinions. This suggests students are increasingly motivated in learning IPA on Living Living Lifeal Survival materials.
\end{abstract}

Keywords: Bridge Card, Learning Outcomes, Modification, Science Literacy

\section{PENDAHULUAN}

Proses pembelajaran pada jenjang pendidikan menengah seyogyanya harus interaktif, inspiratif, menyenangkan, dan memotivasi siswa untuk berpartisipasi aktif serta memberikan ruang yang cukup bagi inovasi, kreativitas, dan kemandirian sesuai dengan bakat, minat, dan perkembangan fisik mampu mengembangkan seluruh potensi yang 


\section{JPSP: Jurnal Penelitian Sains dan Pendidikan}

https://e-journal.iain-palangkaraya.ac.id/index.php/mipa/

dimiliki (Yuliati, 2017). Salah satu mata pelajaran yang erat kaitannya dengan kompetensi tersebut adalah IPA, yaitu pengetahuan yang disusun berdasarkan fakta, fenomena-fenomena alam, hasil pemikiran, dan hasil eksperimen yang dilakukan pada ahli (Sudjana, 2000). Dalam perkembangannya, IPA tidak hanya ditandai oleh adanya kumpulan fakta saja, melainkan juga ditandai munculnya metode ilmiah dan sikap ilmiah. Pada tingkat sekolah menengah, Ilmu Pengetahuan Alam atau Sains merupakan salah satu mata pelajaran yang menduduki peranan penting dalam pendidikan hal ini dikarenakan sains dapat menjadi bekal bagi peserta didik dalam menghadapi berbagai tantangan di era global. Oleh karena itu, diperlukan cara pembelajaran yang dapat menyiapkan peserta didik untuk memiliki kompetensi yang baik dan melek sains serta teknologi, mampu berpikir logis, kritis, kreatif, berargumentasi secara benar, dapat berkomunikasi serta berkolaborasi (Gulo, 2019).

Belajar IPA diperlukan bagi setiap orang karena setiap hari orang berhadapan dan menggunakan gejala-gejala, peristiwaperistiwa, serta hukum-hukum Fisika, hanya saja tidak setiap orang menyadari atau mengetahui. Sebagai contoh sewaktu kita memompa ban sepeda sebenarnya kita menggunakan hukum Boyle, sewaktu kita menimbang benda sebenarnya menggunakan hukum keseimbangan rotasi dan translasi, dan sebagainya. Agar proses belajar mengajar IPA memperoleh hasil belajar yang optimal, siswa sebagai subyek belajar sebaiknya dilibatkan secara fisik dan mental pada masalah-masalah kuantifikasi, prediksi, observasi, eksperimen, analisa dan menarik kesimpulan. Proses pembelajaran IPA didalam kelas harus mengutamakan keterlibatan siswa secara aktif untuk menemukan sendiri pengetahuan melalui pengalaman dan interaksi dengan lingkungan.

Pembelajaran IPA bisa dioptimalkan dengan penerapan literasi sains dalam pembelajaran. Hal yang paling pokok dalam pengembangan literasi sains siswa meliputi pengetahuan tentang sains, proses sains, pengembangan sikap ilmiah, dan pemahaman peserta didik terhadap sains sehingga peserta didik bukan hanya sekedar tahu konsep sains melainkan juga dapat menerapkan kemampuan sains dalam memecahkan berbagai permasalahan dan dapat mengambil keputusan berdasarkan pertimbangan-pertimbangan sains. Berdasarkan beberapa pengertian literasi sains tersebut peserta didik diharapkan dapat menerapkan pengetahuan yang didapat di sekolah untuk diterapkan dalam kehidupan sehari-hari sehingga peserta didik dapat memiliki kepekaan dan kepedulian terhadap lingkungan sekitarnya (Oktviani, dkk., 2020).

Berdasarkan hasil observasi di MTs N 4 Ngawi, pemahaman siswa tentang konsep kelangsungan hidup makhluk hidup perlu ditingkatkan karena konsep ini merupakan materi yang mudah karena ada disekitar kita, namun kenyataannya sulit dipelajari oleh siswa berdasarkan nilai ulangan harian. Dalam penyampaian materi guru masih menggunakan metode yang tidak sesuai dengan karakteristik 


\section{JPSP: Jurnal Penelitian Sains dan Pendidikan}

https://e-journal.iain-palangkaraya.ac.id/index.php/mipa/

IPA, maka harus dicari solusi yang tepat agar dapat meningkatkan hasil belajar siswa.

Amri dan Ahmadi (2010) menyatakan bahwa untuk membangkitkan minat dan pemahaman belajar siswa, guru harus mengubah paradigma dari mengajar (teacher centered) menjadi paradigma belajar (student centered) sebagai usaha mempersiapkan siswa agar belajar mandiri (independent learners) dan guru hanya sebagai fasilitator. Kebiasaan siswa diera digitalisasi yaitu siswa lebih suka bermain smartphone daripada membaca bukubuku pelajaran sehingga minat baca rendah. Padahal dengan membaca siswa diberi kesempatan untuk merekonstruksi pengetahuan yang mereka miliki dengan melibatkan semua emampuannya termasuk bermain dan berimajinasi.

Salah satu metode mengajar yang bisa menumbuhkan keinginan siswa untuk menemukan sesuatu dengan cara bermain adalah dengan bridge card atau bridge card yang sudah dikombinasi dengan budaya baca / literasi (Devega, 2016). Hal ini dilakukan mengingat lingkungan siswa pada saat ada acara hajatan kartu ini selalu hadir, jadi mau tak mau siswa akhirnya sering melihat dan berinteraksi.

Penyajian materi IPA hendaknya menggunakan metode mengajar dan media pembelajaran yang melibatkan proses bermain tanpa meninggalkan kaidah ilmiah, norma agama sehingga dapat menumbuhkan sikap ilmiah pada diri siswa. Media pembelajaran yang bisa kita manfaatkan dalam proses belajar mengajar adalah media pembelajaran yang berupa permainan salah satunya bridge card yang dimodifikasi dengan literasi sains (Wulandari dkk., 2020). Suatu permainan anak-anak yang bisa kita rancang dengan membuat suatu inovasi dengan soal-soal pertanyaan yang ingin mengetahui pemahaman siswa tentang suatu materi. Diharapkan dengan bermain dan bertanya lewat media gambar / cara seperti memainkan bridge card tetapi diganti kartu yang bergambar makhluk hidup dengan berbagai jenis adaptasi, siswa akan senang belajar IPA. Adapun tujuan dalam penelitian ini adalah untuk meningkatkan hasil belajar IPA pada pokok bahasan kelangsungan hidup makhluk hidup pada siswa kelas IX A MTsN 4 Ngawi melalui modifikasi literasi sains dan bridge card.

\section{METODE PENELITIAN}

Jenis penelitian ini merupakan penelitian tindakan kelas dengan subjek penelitian yaitu kelas IX A MTsN 4 Ngawi sebanyak 30 siswa. Jumlah putaran dalam penelitian tindakan kelas ini sebanyak dua siklus yang terdiri dari tahap perencanaan, tindakan, observasi/pengamatan, dan refleksi (Suharsimi, 2006). Siklus I untuk mengetahui hasil belajar siswa dalam mengikuti pembelajaran pada materi Kelangsungan Hidup dan hasil refleksi pada siklus I, digunakan untuk tindakan pada siklus II. Bagan siklus penelitian tindakan kelas dapat dilihat pada gambar 1 berikut ini. 
https://e-journal.iain-palangkaraya.ac.id/index.php/mipa/

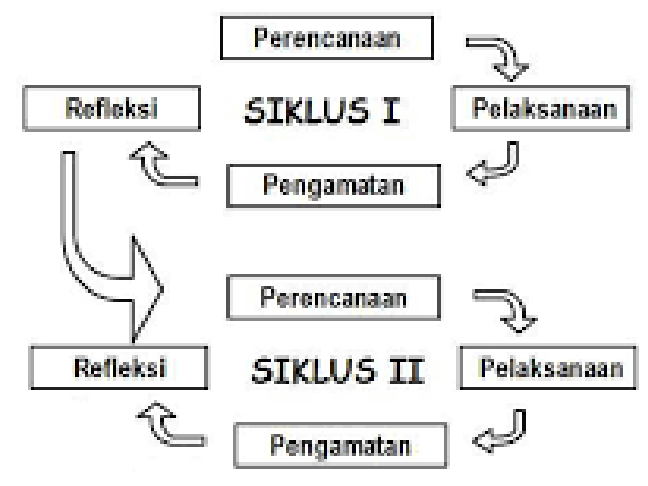

Gambar 1. Bagan Siklus Penelitian

Teknik pengumpulan data menggunakan angket, observasi dan tes. Angket digunakan untuk memperoleh informasi tentang minat siswa terhadap pembelajaran yang berlangsung, sedangkan observasi (pengamatan langsung) oleh peneliti dan kolaborator digunakan untuk mengamati aktivitas dan sikap siswa pada saat proses pembelajaran. Adapun tes, dilakukan untuk mengetahui hasil belajar siswa setelah mengikuti kegiatan pembelajaran (pra tindakan, maupun tiap akhir siklus). Data dalam penelitian dikumpulkan melalui pedoman angket, lembar observasi maupun butir soal. Adapun teknik analisis data menggunakan deskriptif analitik dengan tahapan analisis menurut Miles dan Huberman yaitu: reduksi data, penyajian data dan penarikan kesimpulan.

\section{HASIL}

Hasil penelitian pada siklus I diperoleh sebagai berikut: (1) Perencanaan, pada tahap ini dipersiapkan perangkat pembelajaran yang terdiri dari RPP I, soal tes I dan alat-alat pembelajaran yang mendukung serta lembar pengamatan keaktifan siswa; (2) Pelaksanaan, pada tahap ini dilaksanakan pembelajaran dengan menggunakan model pembelajaran yang memodifikasi literasi sains dengan bridge card. Peneliti bertindak sebagai guru sedangkan sebagai observer dilakukan oleh rekan sejawat; (3) Observasi, pada akhir pembelajaran diberikan tes kepada siswa dengan tujuan untuk mengetahui keberhasilan dalam proses pembelajaran; (4) Refleksi, berdasarkan hasil tes pada siklus I diperoleh nilai rata-rata hasil belajar siswa sebesar 66,66\%. Adapun untuk aktivitas siswa diperoleh skor rata-rata sebesar 76,66\%. Hal ini menunjukkan bahwa proses pembelajaran belum memenuhi kriteria keberhasilan. Oleh karena itu, proses pembelajaran dilanjutkan pada siklus II. Berdasarkan hasil refleksi, diperoleh beberapa kekurangan-kekurangan di dalam proses pembelajaran pada siklus I yaitu guru belum terampil dalam memotivasi siswa, guru tidak menyampaikan tujuan pembelajaran saat proses pembelajaran, dan guru belum dapat mengelola waktu dengan baik terutama pada saat proses membimbing latihan kepada siswa.

Hasil penelitian pada siklus II diperoleh sebagai berikut: (1) Perencanaan, pada tahap ini dipersiapkan perangkat pembelajaran yang terdiri dari RPP II, soal tes II dan alat-alat pembelajaran yang mendukung serta lembar pengamatan keaktifan siswa; (2) Pelaksanaan, pada tahap ini dilaksanakan pembelajaran dengan menggunakan model pembelajaran yang memodifikasi literasi sains dengan bridge card. Peneliti bertindak sebagai guru sedangkan sebagai observer dilakukan oleh rekan sejawat. Pada akhir pembelajaran 


\section{JPSP: Jurnal Penelitian Sains dan Pendidikan}

https://e-journal.iain-palangkaraya.ac.id/index.php/mipa/

diberikan tes kepada siswa dengan tujuan untuk mengetahui keberhasilan dalam proses pembelajaran; (3) Refleksi, berdasarkan hasil tes pada siklus II diperoleh nilai rata-rata hasil belajar siswa sebesar $83,33 \%$. Adapun untuk aktivitas siswa diperoleh skor rata-rata sebesar 70\%. Hal ini menunjukkan bahwa proses pembelajaran telah memenuhi kriteria keberhasilan. Oleh karena itu, proses pembelajaran berhenti pada siklus II. Berdasarkan hasil refleksi, pada siklus II guru telah menerapkan pembelajaran dengan baik hal ini dilihat dari siswa yang rata-rata sudah aktif dalam pembelajaran dan hasil belajar siswa sudah mencapai kategori tuntas.

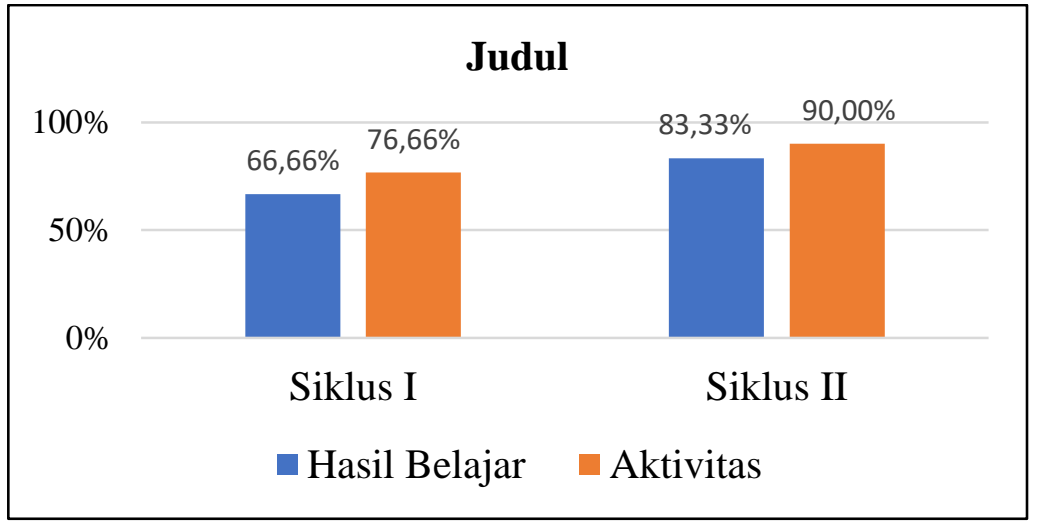

Gambar 2. Data Hasil Belajar dan Aktivitas Siswa Pada Siklus I dan II

\section{PEMBAHASAN}

Data tentang hasil belajar dan aktivitas siswa dapat dilihat pada Gambar 2. Pada Gambar 2 tersebut menunjukkan bahwa pada siklus I siswa secara klasikal keberhasilan belajar siswa mencapai $66,66 \%$, sedangkan siklus II mencapai 83,33 \%,. Siklus I belum mencapai kriteria ketuntasan sedangkan siklus II telah mencapai kriteria ketuntasan. Ini menunjukkan bahwa tingkat keberhasilan siswa dari siklus ke siklus mengalami peningkatan. Peningkatan ini disebabkan oleh guru yang semakin mengerti dan memahami langkah-langkah pembelajaran sehingga proses belajar mengajar berlangsung lebih baik. Terjadi Peningkatan sebesar 16,67\%.
Pada siklus I hasil pengamatan menyatakan bahwa rata-rata aktivitas siswa masih kurang $(76,66 \%)$. Pada siklus II ratarata aktivitas siswa sudah mencapai kategori aktif (90\%). Terjadi peningkatan aktivitas siswa sebesar $13,34 \%$. Peningkatan ini terutama pada aktivitas diskusi dengan mennggunakan kartu antar siswa dan kemauan siswa dalam menyampaikan pendapatnya. Hal ini menunjukkan siswa semakin termotivasi dalam belajar IPA pada materi Kelangsungan Hidup Makhluk Hidup.

Hasil penelitian ini sejalan dengan penelitian Intalina (2020) yang menjelaskan bahwa media pembelajaran berbasis kartu bridge dapat meningkatkan aktivitas dan hasil belajar siswa pada mata pelajaran biologi 
https://e-journal.iain-palangkaraya.ac.id/index.php/mipa/

materi pokok sistem ekskresi. Selain itu, penggunaan media bridge card game dapat meningkatkan kreativitas dan kemampuab berpikir analitis siswa. (subandiyantoro dkk., 2018).

\section{SIMPULAN}

Model pembelajaran dengan memodifikasi literasi sains dengan bridge card memiliki dampak positif dalam meningkatkan hasil belajar IPA siswa dalam materi kelangsungan hidup makhluk hidup kelas IX A MTsN 4 Ngawi yang ditandai dengan peningkatan ketuntasan belajar siswa sebesar $16,67 \%$, yaitu dari siklus I $(66,66 \%)$, dan siklus II $(83,33 \%)$.

Selain itu, model pembelajaran dengan memodifikasi literasi sains dengan bridge card memiliki dampak positif dalam meningkatkan motivasi siswa dalam materi kelangsungan hidup makhluk hidup kelas IX A MTsN 4 Ngawi yang ditandai dengan meningkatnya aktivitas siswa sebesar 13,34\% yaitu dari siklus I (76,66 \%) dan siklus II $90 \%$.

\section{DAFTAR PUSTAKA}

Amri S, Ahmadi LK. 2010. Proses Pembelajaran Inovatif dan Kreatif dalam kelas. Metode, Landasan Teori-Praktis dan Penerapannya. Jakarta: Prestasi Pustaka.

Devega, Younela. (2016). Pengaruh Penggunaan Media Bridge card Terhadap Kemampuan Menulis Kalimat Pinyin pada Siswa Kelas XII APH 2 SMK YPM 2 Taman Sidoarjo. Jurnal Mandarin UNESA, 1(1).
Gulo S. 2019. Tantangan Pendidikan di Era Revolusi 4.0. Online. https://www.kompasiana.com/. Diunduh tanggal 14 Januari 2020.

Intaliana, Vincentia Yosefine (2020) Pengembangan media pembelajaran kartu bridge berbasis soal HOTS pada materi sistem ekskresi manusia untuk siswa SMA kelas XI. Skripsi Thesis, Sanata Dharma University.

Sudjana N. 2000. Dasar-Dasar Proses Belajar Mengajar. Bandung : Sinar Baru Algensindo.

Oktaviani D, Andari KDW, Bua AT. 2020. Pengembangan Media Papan Baca Pintar Berbasis Literasi Sains Di SDN 011 Tarakan. Jurnal Pena Karakter. 2(2): 1-7.

Subandiyantoro S, Prayitno BA, Masykuri M. 2018. Penggunaan Model Problem Solving Dan Model Problem Posing Disertai Bridge Card Game Terhadap Prestasi Belajar Biologi Ditinjau Dari Kreativitas Dan Kemampuan Berpikir Analitis Siswa Kelas X MA Wahidiyah Kota Kediri Tahun Pelajaran 2015/2016. Inkuiri: Jurnal Pendidikan IPA. 7(3):

Suharsimi Arikunto. 2006. Penelitian Tindakan Kelas. Jakarta: Bumi Aksara.

Djamarah SB. 2000. Guru dan Anak-Anak Didik Dalam Interaksi Edukatif. Jakarta: Rineka Cipta.

Wulandari I, Hendrian J, Sari IP, Arumningtyas F, Siahaan RB, Yasin H. 2020. Efektivitas Permainan Kartu sebagai Media Pembelajaran Matematika. E-Dimas Jurnal Pengabdian kepada Masyarakat. 11(2):127-131. 
JPSP: Jurnal Penelitian Sains dan Pendidikan

https://e-journal.iain-palangkaraya.ac.id/index.php/mipa/

Yuliati Y. 2017. Literasi Sains Dalam Pendas. 3(2): 21- 28.

Pembelajaran IPA. Jurnal Cakrawala 